\title{
Kajian Literatur: Perawatan Mulut sebagai Intervensi Pencegahan Ventilator-Associated Pneumonia pada Pasien Kritis
}

\author{
Nindya Rachma Gardhika Sari ${ }^{1}$, Reni Sulung Utami ${ }^{1 *}$ \\ ${ }^{1}$ Departemen Ilmu Keperawatan Fakultas Kedokteran, Universitas Diponegoro, Semarang Indonesia \\ reni.sulung@fk.undip.ac.id
}

\begin{abstract}
Introduction: Ventilator-Associated Pneumonia (VAP) is a nosocomial pneumonia which develops after the patient received 48 hours of mechanical ventilation intubation. VAP raises various problems such as prolong length of stay and ventilator time, increase treatment costs, and increase risk of death. Appropriate and effective oral care is one of the nursing interventions that can reduce the incidence of $V A P$. The aim of this study was to identify procedure of oral care for prevention of VAP in critical patients.

Methods: This research method is a literature review. Literature is searched through electronic database such as EBSCOhost, Scopus, Science Direct, and Proquest. The inclusion criteria of article were randomized controlled trials or randomized clinical trial designs, evaluate oral care effects on the prevention of VAP in critically ill patients, full text articles and publication years from January 2013 to May 2020.

Results: Search results found as many as 38 articles, but only 9 articles were eligible to be reviewed. This review indicate that oral care has a significant effect on the prevention of VAP. The combination of toothbrush and swab is the most appropriate equipment. Chlorhexidine $2 \%$ was the most influential solution in reducing the incidence of VAP, while the frequency of oral care was most effective when adjusted to the results of the Back Oral Assessment Score (BOAS).

Conclusion: This result reinforces the use of chlorhexidine in the oral care of mechanically ventilated patients. Oral care assessment needs to be done by nurses to guide in determining the frequency of oral care.
\end{abstract}

Keywords: Critical Care, Oral Care, Oral Hygiene, Ventilator-Associated Pneumonia.

\begin{abstract}
Abstrak
Pendahuluan: Ventilator-Associated Pneumonia (VAP) merupakan suatu penyakit pneumonia nosokomial yang berkembang setelah pasien menerima 48 jam pemasangan intubasi ventilasi mekanik. VAP menimbulkan berbagai permasalahan bagi pasien kritis di ICU seperti perpanjangan waktu rawat dan waktu ventilator, peningkatan biaya perawatan, dan peningkatan risiko kematian. Perawatan mulut yang tepat dan efektif menjadi salah satu intervensi keperawatan yang dapat mengurangi insiden VAP. Tujuan penelitian ini untuk mengidentifikasi perawatan mulut yang dapat mencegah VAP pada pasien kritis.

Metode: Penelitian ini mengunakan metode kajian literatur. Penelusuran literatur dilakukan melalui database elektronik seperti EBSCOhost, Scopus, Science Direct, dan Proquest. Kriteria inklusi yang digunakan adalah desain penelitian randomized controlled trials atau randomized clinical trial, menguji efek perawatan mulut pada pencegahan VAP, artikel full text dan dipublikasikan dari Januari 2013 sampai Mei 2020.
\end{abstract}


Hasil: Hasil penelusuran ditemukan sebanyak 38 artikel, tetapi hanya 9 artikel yang memenuhi kriteria untuk ditelaah. Hasil review menunjukkan bahwa perawatan mulut memiliki efek yang signifikan pada pencegahan VAP. Kombinasi sikat gigi dan cotton swab merupakan peralatan yang paling tepat. Chlorhexidine 2\% menjadi larutan yang paling berpengaruh pada pengurangan kejadian VAP, sedangkan frekuensi perawatan mulut yang paling efektif menyesuaikan dengan hasil pengkajian Back Oral Assessment Score (BOAS).

Kesimpulan: Hasil ini memperkuat penggunaan chlorhexidine dalam perawatan oral pasien dengan ventilasi mekanik. Penilaian perawatan mulut perlu dilakukan oleh perawat untuk menentukan frekuensi perawatan mulut yang akan diberikan kepada pasien.

Kata Kunci: Perawatan Kritis, Kebersihan Mulut, Ventilator-Associated Pneumonia.

\section{PENDAHULUAN}

Pasien kritis memiliki refleks yang terganggu dan cenderung mengalami aspirasi paru sehingga berisiko mengalami infeksi pernafasan salah satunya VentilatorAssociated Pneumonia (VAP) (Gaddey, 2017). Insiden VAP pada pasien kritis berkisar antara 5\% hingga 67\% (Timsit et al., 2017), sedangkan angka kejadian VAP di negara-negara Asia berkisar antara 2,5\%48,1\% (Abdelrazik \& Salah, 2017).VAP menimbulkan berbagai permasalahan bagi pasien kritis di Intensive Care Unit (ICU) yaitu perpanjangan Length of Stay (LOS) selama 10-20 dan perpanjangan Length of Ventilation (LOV) sebanyak 10-17,4 hari. Rata-rata jumlah biaya tambahan pasien dengan VAP sebanyak \$6.250,92\$41.294,00 (Mathai et al., 2015; Zubair et $a l ., 2017)$. Selain itu, risiko peningkatan kematian pada pasien dengan VAP adalah sebanyak 24\%-76\% (Zubair et al., 2017).

Perawatan mulut yang tepat berperan penting dalam mengurangi terjadinya VAP. Sebuah penelitian dengan melakukan intervensi perawatan mulut dengan sikat gigi bayi dan larutan chlorehexidine selama 5 hari berturut-turut pada kelompok intervensi menunjukkan perbedaan antara kelompok kontrol yang mengalami VAP sebanyak 9 dari 38 orang dan kelompok intervensi yang mengalami VAP hanya 3 dari 38 orang (Atashi et al.,
2018). Dalam penelitian yang lain menunjukkan bahwa risiko terjadinya VAP di ICU menurun dari $24 \%$ menjadi $18 \%$ setelah perawat menerapkan intervensi perawatan mulut (Hua et al., 2016)

Terdapat beberapa fenomena mengenai praktik perawatan mulut pada pasien kritis di ruang ICU. Miranda (2016) menunjukkan sebanyak $49,3 \%$ perawat menggunakan spatula khusus, kain kasa, dan sikat gigi sebanyak, perawat yang hanya sikat gigi sebanyak $28,2 \%$. Frekuensi perawatan mulut dalam dua kali sehari sebanyak $46,5 \%$ dan tidak pernah membersihkan sebanyak 11,3\% (Ibrahim, Mudawi, \& Omer, 2015). Pada penelitian yang lain dengan responden sebanyak 131 perawat di unit perawatan kritis sebanyak $80 \%$ melaksanakan perawatan mulut minimal satu kali sehari, 20,4\% perawat menggunakan sikat gigi dengan $2 \%$ Chlorhexidine Solution dan $75,8 \%$ perawat menggunakan oral swab dengan $2 \%$ Chlorhexidine Solution (Maulana, Sumardi, \& Koesoemadinata, 2016).

Review mengenai perawatan mulut dalam pencegahan VAP telah dilakukan dengan judul "Oral hygiene care for critically ill patients to prevent ventilatorassociated pneumonia (Review) Summary of Findings for The Main Comparison" (Hua et al., 2016). Penelitian tersebut hanya 
berfokus pada cairan yang digunakan sehingga peneliti beranggapan perlu pengembangan penelitian dengan konsep terkait agar nantinya ada perbaikan dalam praktik perawatan mulut pada pasien kritis. Berdasarkan uraian di atas, peneliti tertarik untuk menggali atau mengidentifikasi perawatan mulut yang efektif untuk pencegahan VAP pada pasien kritis.

\section{METODE}

Jenis penelitian yang digunakan adalah Literature Review atau kajian literatur. Kajian literatur ini dilakukan dengan melaksanakan penelusuran literatur di database penelitian elektronik yaitu Scopus, Ebsco, Proquest, dan Science Direct. Kata kunci yang digunakan adalah "oral care", "oral hygiene", "mouth care”, "oral health care”, "critically ill", "critical care", "critical area", "critical patients", "intensive care unit", "Ventilator-associated pneumonia", "VAP", "hospital-associated pneumonia", "VAP prevention", "randomized trial", "review". Kata kunci tersebut digabungkan dengan menggunakan operator seperti "OR", "AND", dan "NOT", kemudian digunakan secara bersamaan di laman advanced search yang ada pada database. Kriteria inklusi artikel yaitu desain penelitian randomized controlled trials atau randomized clinical trial, menguji efek perawatan mulut pada pencegahan VAP, artikel full text dan dipublikasikan dari Januari 2013 sampai Mei 2020. Hasil pencarian literatur diperoleh sebanyak 38 artikel. Sejumlah 29 artikel dieksklusi karena tidak sesuai dengan kriteria inklusi sehingga terdapat sembilan artikel yang ditelaah. Alur pencarian artikel ditampilkan dalam Gambar 1.

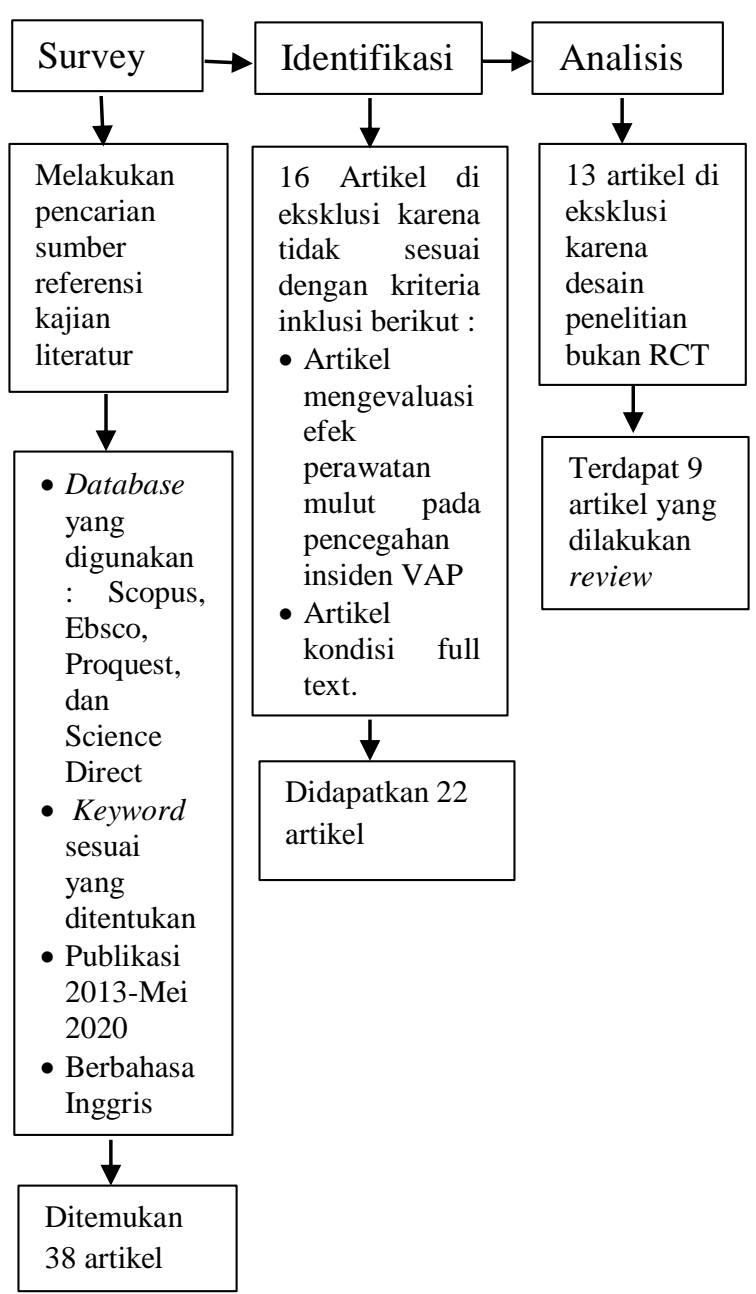

Gambar 1. Diagram alur pencarian artikel

\section{HASIL}

Sebanyak sembilan artikel yang telah dipilih untuk di review seluruhnya merupakan artikel penelitian berbahasa Inggris yang memiliki desain penelitian randomized controlled trial, baik studi prospeketif, single-blind, maupun doubleblind. Seluruh artikel terpublikasi tahun 2013 hingga tahun 2020 dengan detail artikel tahun 2013 sebanyak satu artikel, tahun 2016 sebanyak tiga artikel, tahun 2017 sebanyak tiga artikel, tahun 2018 satu artikel, dan tahun 2020 sebanyak satu artikel. Uji statistik yang digunakan oleh peneliti artikel dalam mengetahui 
signifikasi antar kelompok menggunakan uji Chi Square $(n=7)$, Man Whitney $(n=1)$, dan Fisher $(n=1)$. Review ini melibatkan total 1.309 partisipan dengan kriteria inklusi utama penelitian yaitu pasien kritis dewasa yang telah menerima ventilasi mekanik selama minimal 48 jam dan tidak terdiagnosa mengalami Pneumonia sebelum dilaksanakannya intervensi.

Kelompok kontrol dan kelompok intervensi keduanya mendapatkan perawatan mulut, hanya saja berbeda peralatan, larutan, atau frekuensinya. Sebanyak empat artikel manampilkan perbandingan larutan antara kelompok kontrol dengan kelompok intervensi, sebanyak dua artikel membandingkan perbedaan frekuensi, dan satu artikel membandingkan peralatan perawatan mulut. Sebanyak dua artikel lainnya membandingkan perawatan mulut rutin dengan perawatan mulut kelompok intervensi yang artinya peralatan, larutan, dan frekuensi antar kelompok juga berbeda.

Seluruh artikel mengevaluasi efek perbandingan perawatan mulut pada kejadian VAP pada kelompok kontrol dengan kelompok intervensi. Cara diagnosis pasien dengan VAP menggunakan CPIS, MCPIS, ataupun CFU. Selain itu, seluruh artikel juga melihat signifikasi perbedaan insiden VAP antar kelompok. Sebanyak 5 artikel menunjukkan hasil signifikan dan 4 artikel menunjukkan hasil yang tidak signifikan antar kelompok. Hasil review artikel secara detail ditunjukkan dalam matriks sintesis yang ditampilkan pada Tabel 1.

\section{PEMBAHASAN}

Hasil review menunjukkan secara menyeluruh perawatan mulut berpengaruh pada pengurangan kejadian VAP. Perawatan mulut mampu mencegah kolonisasi faringeal dan mencegah perkembangan laju patogen VAP seperti Streptococcus pneumoniae, Pseudomonas aeruginosa, dan Acinetobacter sp. sehingga kejadian VAP pada pasien kritis juga mampu dicegah (Miranda, 2016). Pemilihan peralatan, larutan, dan frekuensi merupakan elemen dasar perawatan mulut. 1. Peralatan Perawatan Mulut

Peralatan yang paling berpengaruh pada pengurangan kejadian VAP pasien kritis adalah kombinasi dari sikat gigi pediatrik dan swab. Sikat gigi berfungsi dalam mengurangi plak, bakteri dan lendir di area mulut. Sedangkan swab memiliki fungsi dalam membersihkan partikel yang lebih halus dan mampu melembabkan mukosa oral Kombinasi penggunaan kedua alat tersebut memiliki dampak yang lebih efektif dibanding penggunaan sikat gigi atau swab saja, dikarenakan gabungan kedua fungsi yang mampu memaksimalkan perawatan mulut. Sikat gigi pediatrik yang digunakan merupakan standar American Dental Association yaitu berbulu halus, bersiku dan berlevel dengan tujuan meminimalkan abrasi gigi dan gusi berlebih. Karakteristik berikutnya adalah memiliki ujung sikat yang bulat dengan tujuan memudahkan pembersihan ke selasela gigi geraham dan mencegah perlukaan langit-langit mulut (Miranda, 2016). Teknik Bass juga diterapkan dalam menyikat gigi ini sehingga mampu membersihkan kotoran yang menempel di gigi dan gusi secara maksimal (Berry, 2013; Nobahar, Razavi, \& Malek, 2016).

\section{Larutan Perawatan Mulut}

Chlorehexidine (CHX) menjadi larutan yang paling efektif dalam perawatan mulut. Larutan CHX memiliki berbagai macam konsentrasi yaitu $0,12 \%, 0,2 \%$, dan $0,2 \%$. Semakin tinggi konsentrasi larutan $\mathrm{CHX}$ semakin tinggi pula 


\section{Tabel 1. Matriks Sintesis Artikel}

\begin{tabular}{|c|c|c|c|c|c|c|}
\hline No & Penulis & $\begin{array}{c}\text { Design } \\
\text { Penelitian }\end{array}$ & $\begin{array}{c}\text { Sampel } \\
\text { Penelitian }\end{array}$ & Alat Ukur & Bentuk Intervensi & Hasil \\
\hline 1 & (Berry, 2013) & $\begin{array}{l}\text { Prospective } \\
\mathrm{RCT}\end{array}$ & $\begin{array}{l}398 \text { pasien dewasa } \\
\text { ICU } \\
\text { Grup A }(n=138) \\
\text { Grup B }(n=133) \\
\text { Grup C }(n=127)\end{array}$ & $\mathrm{CFU}$ & $\begin{array}{l}\text { Alat: sikat gigi kecil dan lembut } \\
\text { Frekuensi: tiga kali sehari } \\
\text { Larutan: Grup A = grup kontrol yang } \\
\text { menggunakan air seteril } 20 \mathrm{ml} \text {. } \\
\text { Grup B menggunakan larutan sodium } \\
\text { bikarbonat dengan konsentrasi } 6,5 \mathrm{~g} / \mathrm{L} \text {. } \\
\text { Grup C menggunakan larutan Listerin }\end{array}$ & $\begin{array}{l}\text { Insiden kejadian VAP total } 18 \text { pasien } \\
\text { dengan, } \\
\text { grup } A=4,3 \% \text { pasien } \\
\text { grup } B=4,5 \% \text { pasien } \\
\text { grup } C=4,7 \% \text { pasien } \\
\text { Tidak signifikan insiden VAP antar } \\
\text { grup ( } p-0,92)\end{array}$ \\
\hline 2 & $\begin{array}{l}\text { (Moustafa \& } \\
\text { Tantawey, 2016) }\end{array}$ & $\mathrm{RCT}$ & $\begin{array}{l}60 \text { pasien General } \\
\text { Intensive Care } \\
\text { Unit (GICU) }\end{array}$ & $\begin{array}{l}\text { VAP: } \quad \text { CPIS } \\
\text { Kesehatan mulut: } \\
\text { Eilers Barnason } \\
\text { Oral Assesement }\end{array}$ & $\begin{array}{l}\text { Kelompok kontrol perawatan mulut rutin } \\
\text { dengan swabbing dengan larutan NS 0,9\% } \\
\text { Frekuensi: satu kali sehari } \\
\text { Kelompok intervensi menggunakan sikat } \\
\text { gigi pediatrik dan pasta gigi, dilanjutkan } \\
\text { aplikasi swab CHX Glukonat } 0,12 \% \\
\text { Frekuensi: dua kali sehari }\end{array}$ & $\begin{array}{l}\text { Kejadian VAP } \\
\text { Grup kontrol: } 50 \% \\
\text { Grup intervensi: } 16,7 \% \text { dengan nilai } \\
\text { p=0,0006 yang menunjukkan sangat } \\
\text { signifikan kejadian VAP antara grup } \\
\text { kontrol dengan grup intervensi }\end{array}$ \\
\hline 3 & $\begin{array}{l}\text { (Nobahar, } \\
\text { Razavi, \& } \\
\text { Malek, 2016) }\end{array}$ & $\mathrm{RCT}$ & $\begin{array}{l}68 \text { pasien } \\
\text { Gritis } \\
(n=34) \quad \text { kontrol } \\
\text { intervensi }(n=34)\end{array}$ & MCPIS & $\begin{array}{l}\text { Peralatan: } s w a b \\
\text { Frekuensi: dua kali sehari } \\
\text { Larutan: } \\
\text { Grup intervensi = swab yang telah } \\
\text { direndam pada HP 3\% selama } 15 \text { menit. } \\
\text { Grup kontrol = swab dengan NS 0,9\% yang } \\
\text { telah direndam } 15 \text { menit. }\end{array}$ & $\begin{array}{l}\text { Insiden VAP } \\
\text { Grup Kontrol: } 38,2 \% \\
\text { Grup intervensi: } 14,7 \% \\
\text { Risiko VAP 2,6 kali lebih besar pada } \\
\text { grup kontrol banding grup intervensi } \\
(\mathrm{RR}=2,6,95 \% \text { CI: } 1,04-6,49, \quad \mathrm{p}= \\
0,0279)\end{array}$ \\
\hline
\end{tabular}




\begin{tabular}{|c|c|c|c|c|c|c|}
\hline No & Penulis & $\begin{array}{c}\text { Design } \\
\text { Penelitian }\end{array}$ & $\begin{array}{c}\text { Sampel } \\
\text { Penelitian }\end{array}$ & Alat Ukur & Bentuk Intervensi & Hasil \\
\hline 4 & $\begin{array}{l}\text { (Haghighi et al., } \\
\text { 2017) }\end{array}$ & $\mathrm{RCT}$ & \begin{tabular}{lr} 
& \multicolumn{3}{l}{ pasien } & kritis \\
Grup $\quad$ kontrol \\
$(\mathrm{n}=50) \quad$ grup \\
intervensi & $(\mathrm{n}=50)$
\end{tabular} & $\begin{array}{l}\text { BOAS, MPS, dan } \\
\text { CPIS }\end{array}$ & $\begin{array}{l}\text { Alat: sikat gigi pediatrik dan pasta gigi } \\
\text { Grup kontrol: tanpa larutan Frekuensi } 1 x \\
\text { sehari. } \\
\text { Grup intervensi: Dibilas dengan NS } 0,9 \% \\
\text { dan cairan CHX } 0,2 \% \text {. Frekuensi sesuai } \\
\text { hasil BOAS }\end{array}$ & $\begin{array}{l}\text { Insiden VAP } \\
\text { Hari ke } 3 \text { dan hari ke lima pada } \\
\text { kelompok kontrol adalah } 10 \% \text { dan } \\
14 \% \text {, dan } 4 \% \text { dan } 10 \% \text { pada kelompok } \\
\text { intervensi. } \\
\text { MPS indeks memiliki perbedaan } \\
\text { signifikan antara kedua grup } \\
(\mathrm{p}<0,001) \text { dengan uji Mann Whitney }\end{array}$ \\
\hline 5 & $\begin{array}{l}\text { (Chacko et al., } \\
\text { 2017) }\end{array}$ & $\begin{array}{l}\text { RCT- double } \\
\text { blind study }\end{array}$ & $\begin{array}{l}206 \text { pasien, Grup } \\
\text { kontrol } \quad(\mathrm{n}=102) \\
\text { grup intervensi } \\
(\mathrm{n}=104)\end{array}$ & $\begin{array}{l}\text { Kriteria VAP dari } \\
\text { CDC }\end{array}$ & $\begin{array}{l}\text { Frekuensi sama: } 3 \text { kali } \\
\text { Grup kontrol: perawatan oral rutin dengan } \\
\text { spons/swab yang direndam } \mathrm{CHX} \text { gluconate } \\
0,2 \% \text {. } \\
\text { Grup intervensi: perawatan mulut dengan } \\
\text { sikat gigi dilanjutkan Chlorhexidine } \\
\text { gluconate } 0,2 \%\end{array}$ & $\begin{array}{l}\text { Insiden VAP pada total sampel: } 12 \\
\text { orang (10,1/1000 ventiator hari) } \\
\text { Grup kontrol: } 7 \text { orang }(11,6 / 1000 \\
\text { ventilator hari) } \\
\text { Grup intervensi: } 5 \text { orang }(8,6 / 1000 \\
\text { ventilator hari) } \\
\text { Tiidak ada perbedaan signifikan antar } \\
\text { kedua grup }(\mathrm{p}=0,82)\end{array}$ \\
\hline 6 & $\begin{array}{l}\text { (Zand et al., } \\
\text { 2017) }\end{array}$ & RCT & $\begin{array}{l}\text { 114 pasien } \\
\text { Grup kontrol } \\
(\mathrm{n}=57) \\
\text { Grup intervensi } \\
(\mathrm{n}=57)\end{array}$ & CPIS & $\begin{array}{l}\text { Alat: sikat gigi pediatrik teknik bass } \\
\text { Frekuensi: } 2 \text { kali } \\
\text { Grup kontrol dengan } 0,2 \% \mathrm{CHX} \\
\text { Grup intervensi menggunakan } 2 \% \mathrm{CHX}\end{array}$ & $\begin{array}{l}\text { Insiden VAP } \\
\text { Grup kontrol 22,8\% } \\
\text { Grup intervensi 5,3\% } \\
\text { Terdapat perbedaan signifikan } \\
\text { kejadian VAP pada kedua kelompok } \\
(\mathrm{p}=007)\end{array}$ \\
\hline 7 & $\begin{array}{l}\text { (Vidal et al., } \\
\text { 2017) }\end{array}$ & $\mathrm{RCT}$ & $\begin{array}{l}213 \text { pasien Grup } \\
\text { kontrol } \quad(n=108)\end{array}$ & CFU & $\begin{array}{l}\text { Frekuensi sama: setiap } 12 \text { jam } \\
\text { Grup kontrol: menggunakan swab kapas } \\
\text { CHX } 0,12 \% 15 \mathrm{ml}\end{array}$ & $\begin{array}{l}\text { Insiden kejadian VAP pada kelompok } \\
\text { kontrol sebanyak } 28 \text { pasien }(62,2 \%) \\
\text { dan pada kelompok intervensi hanya }\end{array}$ \\
\hline
\end{tabular}




\begin{tabular}{|c|c|c|c|c|c|c|}
\hline No & Penulis & $\begin{array}{c}\text { Design } \\
\text { Penelitian }\end{array}$ & $\begin{array}{c}\text { Sampel } \\
\text { Penelitian }\end{array}$ & Alat Ukur & Bentuk Intervensi & Hasil \\
\hline & & & $\begin{array}{l}\text { grup intervensi } \\
(\mathrm{n}=105) .\end{array}$ & & $\begin{array}{l}\text { Grup intervensi; dilakukan dengan sikat } \\
\text { gigi dahulu baru dilanjutkan dengan gel } \\
\text { CHX } 0,12 \%\end{array}$ & $\begin{array}{l}\text { sebesar } 17 \text { pasien }(37,8 \%) \text {. Tidak ada } \\
\text { perbedaan signifikan } \quad(p=0,084) \\
\text { dengan uji Chi Square }\end{array}$ \\
\hline
\end{tabular}

\begin{tabular}{|c|c|c|c|c|c|c|}
\hline 8 & $\begin{array}{l}\text { (Atashi et al., } \\
\text { 2018) }\end{array}$ & $\mathrm{RCT}$ & \begin{tabular}{lr}
\multicolumn{2}{l}{80 pasien } \\
Grup $\quad$ kontrol \\
$(\mathrm{n}=40)$ & grup \\
intervensi & $(\mathrm{n}=40)$
\end{tabular} & BOAS, CPIS & $\begin{array}{l}\text { Alat: sikat gigi pediatrik dilanjutkan swab } \\
\text { Larutan: CHX } 0,2 \% \\
\text { Frekuensi: } \\
\text { Grup kontrol = dua kali sehari } \\
\text { Grup intervensi = Frekuensi menyesuaikan } \\
\text { dengan hasil pengkajian BOAS }(12,8,6,4 \\
\text { jam sekali) }\end{array}$ & $\begin{array}{l}\text { Frekuensi kejadian VAP di hari ke } 3 \\
\text { dan hari ke 5, pada kelompok kontrol } \\
\text { adalah } 15,8 \% \text { dan } 23,7 \% \text {, pada } \\
\text { kelompok intervensi adalah } 10,5 \% \\
\text { dan 7,9\%. Tidak ada perbedaan } \\
\text { signifikan (p=0,059) dengan uji Chi } \\
\text { Square }\end{array}$ \\
\hline 9 & $\begin{array}{l}\text { (Irani, Sargazi, \& } \\
\text { Dahmardeh, } \\
\text { 2020) }\end{array}$ & $\begin{array}{l}\text { RCT- single } \\
\text { blind }\end{array}$ & $\begin{array}{lr}70 \text { pasien } \\
\text { Grup } \quad \text { kontrol } \\
(n=35) \quad \text { grup } \\
\text { intervensi }(n=35)\end{array}$ & BOAS, MCPIS & $\begin{array}{l}\text { Alat: } S w a b \\
\text { Frekuensi: hasil BOAS } \\
\text { Larutan: } \\
\text { Grup kontrol = pasien mendapat swab } \\
\text { dengan chx } 0,2 \% \\
\text { Grup intervensi = swab miswak yang telah } \\
\text { direbus selama } 15 \text { menit }\end{array}$ & $\begin{array}{l}\text { Pada kelompok kontrol terdapat } 6 \\
\text { pasien }(17,1 \%) \text { yang mengalami VAP } \\
\text { dan pada kelompok intervensi tidak } \\
\text { ada yang mengalami VAP. Terdapat } \\
\text { perbedaan signifikan ( } \mathrm{p}=0,01) \text { dengan } \\
\text { uji Fisher's Exact }\end{array}$ \\
\hline
\end{tabular}

MCPIS: Modified Clinical Pulmonary Infection Score; BOAS: Beck Oral Assessment Scale ; CFU: Colony Forming Units; MPS: Mucosal Plaque Score; CPIS: Clinical Pulmonary Infection Score; CDC: Centers for Disease Control; VAP: Ventilator Associated Pneumonia. 
keefektifitasannya dalam pencegahan kejadian VAP. CHX merupakan cairan antiseptik dengan spektrum yang luas, mampu melawan bakteri gram negatif patogen VAP, dan berfungsi sebagai anti plak mukosa (Timsit et al., 2017). Meskipun larutan ini memiliki efek samping pada perubahan warna gigi jika digunakan dalam jangka panjang, Institute for Health Improvement (IHI) tetap menyarankan larutan ini sebagai perawatan mulut dalam Bundel VAP (Hua et al., 2016). Pada penelitian yang membandingkan cairan NS $0,9 \%$ dengan CHX 0,12\% menunjukkan perbedaan yang signifikan terkait kejadian VAP (Moustafa \& Tantawey, 2016). Hal tersebut dapat terjadi karena NS 0,9\% hanya berfungsi untuk membantu perbaikan jaringan mukosa oral yang rusak bukan untuk mencegah perkembangan patogen VAP. Pada penelitian lain yang dilakukan (Zand et al., 2017) yang membandingkan efek perawatan mulut dengan larutan $\mathrm{CHX} 0,2 \%$ dengan CHX 2\% menunjukkan kelompok CHX 2\% memiliki hasil yang lebih baik. Hal tersebut dikarenakan semakin tinggi konsentrasi larutan Chlorehexidine yang digunakan maka akan semakin efektif dalam pencegahan VAP (Guler \& Turk, 2018).

Larutan Sodium Bikarbonat dan Hidrogen Peroksida tidak disarankan. Sodium Bikarbonat mampu menyebabkan luka bakar mukosa oral. Sedangkan Hidrogen peroksida merupakan larutan yang tergolong dalam oksigen reaktif dan tergolong larutan asidosis yang memicu reaksi abrasi mukosa mulut (Firouzan \& Khezri, 2017). Larutan alternatif ekstrak miswak masih kurang efektif disbanding CHX dalam melawan patogen VAP $S$. salivarius dan $S$. sanguis dan belum banyak penelitian mengenai kontraindikasi pemakaian siwak ini sebagai larutan perawatan mulut sehingga Chlorhexidine masih menjadi pilihan larutan yang efektif pada perawatan mulut (Moeintaghavi et al., 2012).

3. Frekuensi Perawatan Mulut

Frekuensi yang paling signifikan pada pengurangan insiden VAP adalah frekuensi yang disesuaikan dari hasil BOAS. Frekuensi yang optimal dalam perawatan mulut harus ditentukan untuk setiap individu dengan mempertimbangkan kondisi mulutnya. Instrumen BOAS terdiri dari 5 indikator yaitu kondisi bibir, gusi dan mukosa oral, gigi, lidah, dan saliva. Penilaian akhir diinterpretasikan menjadi 4 kategori yaitu skor 1-5 (tanpa disfungsi) dengan perawatan mulut setiap 12 jam, skor 6-10 (disfungsi ringan) menerima perawatan mulut setiap 8-12 jam, skor 1115 (disfungsi sedang) menerapkaan perawatan mulut setiap 8 jam sekali, dan untuk skor 16-20 (disfungsi parah) harus menerima perawatan mulut setiap 4 jam sekali (Miranda, 2016). BOAS memiliki pengaruh yang signifikan pda penurunan kejadian VAP. Frekuensi perawatan mulut sebanyak satu kali ataupun dua kali sehari jika dibandingkan dengan frekuensi hasil BOAS maka insiden VAP lebih sedikit pada kelompok pasien dengan frekuensi hasil BOAS (Chacko et al., 2017; Haghighi et al., 2017).

Pencegahan insiden VAP tidak hanya dipengaruhi oleh perawatan mulut saja, tetapi Bundle VAP juga ikut andil didalamnya. Hasil review menunjukkan kegiatan Bundle VAP yang dilaksanakan selain perawatan mulut adalah elevasi kepala setinggi $30^{\circ}$, sedasi harian, profilaksis ulserasi gaster, monitoring manset Tracheal Tube (TT), pengaturan tekanan oklusif Endotracheal Cuff antara 22-30 $\mathrm{mmHg}$, penggantian sirkuit ventilator seminggu sekali, dan menggunakan system suction tertutup. Hal tersebut sesuai dengan Bundel VAP yang berasal dari Institute for Health Improvement (IHI) yang 
dikombinasikan dengan bundle dari Centers for Disease Control and Prevention's (CDC). Miranda (2016) dalam penelitiannya menunjukkan bahwa Bundel VAP yang dilakukan mampu mengurangi angka VAP yang cukup signifikan dari 32 kasus per 1.000 ventilator menjadi hanya 12 kasus setelah intervensi.

Penelitian ini menjadi pengembangan dari review yang dilakukan oleh Hua (2016) tentang perawatan mulut sebagai pencegahan VAP yang hanya menyarankan tentang penggunaan Chlorhexidine sebagai larutan perawatan mulut rutin. Pada penelitian ini tidak hanya mengidentifikasi larutan perawatan mulut pada pasien kritis guna mencegah VAP tetapi juga mengidentifikasi peralatan dan frekuensi yang tepat. Selain itu penelitian ini merupakan review yang dilakukan pada artikel yang lebih terbaru sehingga data yang didapatkan lebih terbaru. Penelitian ini memiliki keterbatasan yaitu meskipun semua artikel merupakan penelitian dengan desain yang sama tetapi memiliki kualitas studi yang beragam dan merupakan penelitian dengan skala yang tidak besar.

\section{KESIMPULAN DAN SARAN}

Perawatan mulut yang dilakukan pada pasien kritis khususnya pada pasien yang terintubasi dan menerima ventilasi mekanik memiliki efek yang signifikan pada pencegahan kejadian VAP. Dari hasil review yang telah dilakukan dapat disimpulkan bahwa peralatan perawatan mulut yang efektif dan signifikan terhadap pencegahan insiden VAP adalah penggunaan gabungan sikat gigi pediatrik dan swab. Chlorehexidin (CHX) 0,2\% menjadi larutan yang paling berpengaruh. Sedangkan frekuensi perawatan mulut yang paling efektif merupakan frekuensi yang menyesuaikan hasil pengkajian BOAS yang dilakukan setiap 12 jam pada pasien tanpa disfungsi oral, setiap 8 jam pada pasien dengan disfungsi ringan, setiap enam jam pada pasien dengan disfungsi sedang, dan setiap empat jam pada pasien dengan disfungsi berat.

Hasil review ini diharapkan agar perawat dapat menerapkan perawatan mulut yang sesuai dari penelitian ini sebagai salah satu intervensi Bundle VAP. Studi literatur ini juga dapat dikembangkan untuk membandingkan perawatan mulut yang disarankan dengan perawatan mulut alternatif sehingga dapat mengetahui perawatan mulut yang memiliki efektifitas tinggi dalam pencegahan insiden VAP pada pasien kritis.

\section{UCAPAN TERIMA KASIH}

Peneliti menyampaikan terima kasih kepada semua pihak yang terlibat dalam penelitian ini.

\section{DAFTAR PUSTAKA}

Abdelrazik, A., \& Salah, A. (2017). Ventilator-associated pneumonia in adult intensive care unit prevalence and complications. The Egyptian Journal of Critical Care Medicine, 5(2), 61-63.

Atashi, V., Yousefi, H., Mahjobipoor, H., Bekhradi, R., \& Yazdannik, A. (2018). Effect of oral care program on prevention of ventilatorassociated pneumonia in intensive care unit patients: A randomized controlled trial. Iranian Journal of Nursing and Midwifery Research, 22(6), 431-435.

Berry, A. (2013). A comparison of Listerine ${ }^{\circledR} \quad$ and $\quad$ sodium bicarbonate oral cleansing solutions on dental plaque colonisation and incidence of ventilator associated pneumonia in 
mechanically ventilated patients: A randomised control trial. Intensive and Critical Care Nursing, 29(5), 275-281.

Chacko, R., Rajan, A., Lionel, P., Thilagavathi, Yadav, B., \& Premkumar, J. (2017). Oral decontamination techniques and ventilator-associated pneumonia. British Journal of Nursing, 26(11), 594-599.

Firouzan, A., \& Khezri, A. (2017). A review of the common mouthwashes for oral care utilised by nurses in the critical intubated patients: A literature review of clinical effectiveness. International Journal of Caring Sciences, 7(3), 711-717.

Gaddey, H. L. (2017). Oral manifestations of systemic disease. General Dentistry, 65(6), 23-29.

Guler, E. K., \& Turk, G. (2018). Oral Chlorhexidine against ventilatorassociated pneumonia and microbial colonization in intensive care patients. Western Journal of Nursing Research, 41(6), 901-919.

Haghighi, A., Shafipour, V., BagheriNesami, M., Gholipour Baradari, A., \& Yazdani, J. (2017). The impact of oral care on oral health status and prevention of ventilatorassociated pneumonia in critically ill patients. Australian Critical Care, 30(2), 69-73.

Hua, F., Xie, H., Worthington, H., Furness, S., Zhang, Q., \& Chunjie, L. (2016). Oral hygiene care for critically ill patients to prevent ventilator-associated pneumonia (review) summary of findings for the main comparison. Cochrane Database of Systematic Reviews, 10(10), CD008367.

Ibrahim, S. M., Mudawi, A. M., \& Omer, O. (2015). Nurses' knowledge, attitude and practice of oral care for intensive care unit patients. Open Journal of Stomatology, 5, 179-186.

Irani, H., Sargazi, G., \& Dahmardeh, A. (2020). The effect of oral care with Miswak versus Chlorhexidine on the incidence of ventilatorassociated pneumonia: A clinical trial study. Medical-Surgical Nursing Journal, 8(4), e100387. doi: $10.5812 / \mathrm{msnj} .100387$

Mathai, A. S., Phillips, A., Kaur, P., \& Isaac, R. (2015). Incidence and attributable costs of ventilatorassociated pneumonia (VAP) in a tertiary-level intensive care unit (ICU) in northern India. Journal of Infection and Public Health, 8(2), 127-135. doi: 10.1016/j.jiph.2014.07.005

Maulana, H., Sumardi, U., \& Koesoemadinata, R. (2016). Prevalensi kandidiasis invasif di unit perawatan intensif Rumah Sakit Hasan Sadikin Bandung. Jurnal Penyakit Dalam Indonesia, 6(1), 1-9.

Miranda, A. (2016). Oral health and care at intensive care units. Journal of Nursing \& Care, 05(06), 9-14.

Moeintaghavi, A., Arab, H., Khajekaramodini, M., Hosseini, R., Danesteh, H., \& Niknami, H. (2012). In vitro antimicrobial 
comparison of chlorhexidine, persica mouthwash and miswak extract. Journal of Contemporary Dental Practice, 13(2), 147-152.

Moustafa, M., \& Tantawey, N. (2016). The effect of oral care intervention on the occurrence of ventilatorassociated pneumonia. Gynecology \& Obstetrics, 6(5), 1000383. doi: 10.4172/21610932.1000383

Nobahar, M., Razavi, M., \& Malek, F. (2016). Effects of hydrogen peroxide mouthwash on preventing ventilator-associated pneumonia in patients admitted to the intensive care unit. Brazilian Journal of Infectious Diseases, 20(5), 444-450.

Timsit, J. F., Esaied, W., Neuville, M., Bouadma, L., \& Mourvllier, B. (2017). Update on ventilatorassociated pneumonia. F1000Research, 6, 2061. doi: 10.12688/f1000research.12222.1

Vidal, C., Karla, A., Monteiro Jr, J., Cavalcanti, A., Henriques, A., Oliveira, M., et al. (2017). Impact of oral hygiene involving toothbrushing versus chlorhexidine in the prevention of ventilator-associated pneumonia: A randomized study. $B M C$ Infectious Diseases, 17(1), 1-10.

Zand, F., Zahed, L., Mansouri, P., Dehghanrad, F., Bahrani, M., \& Ghorbani, M. (2017). The effects of oral rinse with $0.2 \%$ and $2 \%$ chlorhexidine on oropharyngeal colonization and ventilator associated pneumonia in adults' intensive care units. Journal of Critical Care, 40, 318-322.

Zubair, S., Ali, H., Zafar, F., Beg, A., Sial, A., Naveed, S., et al. (2017). Ventilator-associated pneumonia (VAP): Clinical strategies, treatment challenges and economic concerns. Journal of Bioequivalence \& Bioavailability, 9(4), 432-436. 